\title{
CONTINUITY, CONTEXT, AND COHERENCE IN THE QUR'ĀN: A BRIEF REVIEW OF THE IDEA OF NAZM IN TAFSİR LITERATURE
}

\author{
Mustansir Mir*
}

\begin{abstract}
This paper looks at several works of tafsīr that identify nazm, or coherence, as a significant feature of the Qur'ann. The authors whose works are examined are Tabarī, Rāzī, Biqūi $\bar{i}$, and Farāhi and Is lāhi _ - the last two, teacher and student, discussed together. It is concluded that modern tafsir, compared with traditional tafsir, is more accepting of the idea of nazm in the Qur'an, and that the Farāhi-Islāhi view of Qur'anic nazm is more plausible than the views of the other exegetes studied.
\end{abstract}

Keywords: Qur'ān, tafsīr, nażm.

\section{Introduction}

I will begin by explaining the senses in which I use the three keywords in the paper's main title-continuity, context, and coherence: by continuity I mean linkage between some or all the verses of a sürah; by context I mean a framework of meaning which is typically created by a set of verses seen to form a cluster and which helps to determine the meaning of one or more verses occurring inside or in the vicinity of that cluster; and by coherence I mean overall, or organic, unity or coherence in a surah. I would like to make three points in regard to this explanation. First, it is not offered as the only possible explanation of the three terms; it is a working description intended to lay the groundwork for discussion in this paper, and will undergo qualification later in the paper. Second, the explanation suggests a certain gradation in terms of complexity, starting, at the basic level, with continuity and ending, at the highest level, with coherence, with context making up the middle. Third, the three

\footnotetext{
Youngstown State University, Youngstown, Ohio, USA.
}

(C) 2013 Al-Bayān Journal.

Published by Department of al-Qur'ān and al-Hadith, Academy of Islamic Studies,

University of Malaya, 50603 Kuala Lumpur - Malaysia. 
keywords can be said to come under the umbrella of the Arabic word nazm, which, along with its derivatives, is inclusive of them, as a few quick examples from Ibn Manẓūr's Lisān al-Arab will show: naẓamtu 'l-lu'lua: jama'tuhü fi l-silki, "I strung [literally, collected] the pearls on a string"; tanāzamati 'l-șukhüru: talāṣaqat, "the boulders cling to, or lie next to, or are contiguous to, each other"); al-nazimu mina

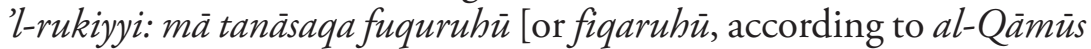
al-Muhit t'] 'alā nasaqin wähidin, "the word naziim is used for a set of wells that have a uniform layout or have been well arranged," that is, wells that have been dug methodically or according to a plan. Taken together, these examples clearly denote continuity and coherence. But the idea of context can also be derived from them, since context presupposes continuity and is itself presupposed in coherence.I will, therefore, use nazm as the mother term for the three keywords, referring sometimes to one, and sometimes to more than one, of them.

We are now ready to inquire how the idea of nazm-in the senses of continuity, context, and coherence-is found in tafsir literature. The review, a selective one, covers the works of the following authors.

1. Abū Ja far Muḥammad ibn Jarīr al-Ṭabarī (224-310/839923).

2. Fakhr al-Dīn Abū 'Abdallāh ibn 'Umar al-Rāzī (544606/1150-1210).

3. Abū 'l-Ḥasan Ibrāhīm ibn 'Umar al-Biqāīi (809-885/14061480)

4. Hamīd al-Dīn al-Farāhī (1863-1930).

5. Amīn Aḥsan Iṣlāḥī (1906-1997).

The last two authors will be discussed together.

A prefatory remark about one of the key terms in the title is in order. I think it goes without saying that none of the authors on our list - and none on any other possible list—would deny, at least

Majd al-Dīn Muhammad ibnYa'qūb al-Fayrūzābādī (Beirut: Dār al-Fikr, 1995), 1048: $n-z-m$.

2 Ibn Manẓūr, Lisān al-Arab, 18 vols. (Beirut: Dār Ihyā̄ al-Turāth al-'Arabī, 1988), 14:196-197: n-z-m. 
theoretically, the existence or significance of nazm-as-context in the Qur'ān. As such, evidence is hardly needed to prove that, in one way or another, all our authors would invoke context to interpret, or accord preference to a certain interpretation of, this or that Qur'anic verse. I will have more to say about context later on. For now, I will focus on continuity and coherence.

\section{Țabarī}

TTabarī's Jämi al-Bayān fì Tafsìr al-Qur'än ${ }^{3}$ typifies the so-called tradition-based exegesis (tafsir bi 'l-ma'thür). Following his standard exegetical procedure, Tabarī introduces a Qur'anic verse with the phrase al-qawlu fì ta'wìli qawlibì ta 'àlä, then offers his understanding of the meaning of the verse, and follows this up with a series of reports, or riwāyat, prefaced with the phrase, wa-bi-nahwi 'lladhi qulnà qäla ablu 'l-ta'wïli; dhikru man qäla dhälika. In his exegetical explanations, Tabarī indicates his support or preference for one riwaya-based explanation of the verse over against another, but it is obvious that he is not interested in discovering nazm-as-continuity or nazm-as-coherence in the Qur'anic text. Occasionally, he seeks to link verses with one another, but, first, his motivation for doing so is not a concern to find any nazm-relationship between versesfor, if that were the case, he would be doing so routinely or more frequently - and, second, the link that he happens to establish between verses hardly has much substance. To take an example: $\mathrm{Q}$ 2:30-39 tells the story of God's installation of Adam as khalifah on earth. The passage begins with the words wa-idh qäla rabbuka, "And when your Lord said." TTabarī says that, according to a certain Basran scholar, ${ }^{4}$ the particle $i d h$, "when," in this verse is redundant and, therefore, dispensable or omissible (anna idh mina 'l-hurüfi 'l-zawälidi wa-anna ma'nāha 'l-hadhfu. Tabarī rejects this view, arguing that the particle $i d h$ in the verse does have a meaning-it indicates an unknown time: wa-yadullu alä majhülin mina 'l-waqti. But then TTabari faces a problem: granted that the $i d h$ is not without meaning, why has it been used in this particular verse, since there is nothing in the preceding verses to which it may be joined by conjunction?

Abū Ja'far Muhammad ibn Jarīr al-Ṭabarī, Jāmi' al-Bayān 'an Tảwìl al-Qur'ān, 30 vols. in 12 (Egypt: Mușṭafā al-Bābī al-Ḥalabī wa-Awlāduhū, 1954).

He is Abū 'Ubayda Ma'mar ibn al-Muthannā (728-825). 
TTabarī answers that, in a preceding verse (28), in which God reminds the Israelites of his blessings upon them-kayfa takfurūna bi 'llāhi wa-kuntum amwätan fa-ahyäkum thumma yumitukum thumma yuhyikum thumma ilayhi turja'una - the meaning of udhkurū is embedded, and that the same meaning is indicated by the particle $i d h$ in idha qäla rabbuka in verse 30 , so that the meaning of udhkuru, directly or indirectly present in both verses, 28 and 30, links the two verses, God thus saying: Remember my blessings upon you and remember when I said to the angels, "I am going to install a caliph on earth." 5 It is not difficult to see that this linkage between the two verses (28 and 30) is a purely grammatical one and has nothing to do with the actual content of the verses involved.

\section{$\mathbf{R} \overline{\mathbf{a} z \overline{\mathbf{1}}}$}

Rāzī is probably the first major mufassir to make a relatively systematic attempt to find nazm in the Qur'ān. He declares that most of the subtleties of the Qur'ān are lodged in the links and relationships between the Qur'anic verses: aktharu lațāifi 'l-Qur'äni müda'atun fì 'l-tartībāti wa-'l-rawābiți. ${ }^{6}$ In his tafsìr, known as Al-Tafsìr al-Kabìr (or Mafätīh al-Ghayb), Rāzì frequently investigates the relationships between the Qur'anic verses as they follow one another, introducing his discussion of such relationships with several more or less fixed phrases, which, in variant forms, include terms like ittiṣa $l$, ta'alluq, and nazm. For example:

ilam anna 'ttiṣāla hādhihì 'l-āyati bi-mā qablahā

fì kayfiyyati ta'alluqi hādhihì 'l-āyati bi-mā qablah $\bar{a}^{8}$

or

\section{i lam anna hädhà muta'alliqun bi-mà taqaddama}

Țabarī, 1:153-154.

In Badr al-Dīn Abū 'Abdallāh Muḥammad ibn Bahādur al-Zarkashī, Al-Burhān fì 'Ulūm al-Qur'ān, 4 vols. in 2, ed. Muhammad Abū 'l-Faḍl Ibrāhīm (Beirut: Dār alMa'rifah), 1:36.

7 Fakhr al-Dīn Abū 'Abdallāh Muhammad ibn 'Umar al-Rāzī, Al-Tafsīr al-Kabìr, 32 vols. in 16 ([Iran]: Maktab al-I'lām al-Islāmī, 1413 H).

$8 \quad$ Ibid., 2:18, at Q 2:2; 9:34, at Q 3:152. 
min qawlihi

fì kayfiyyati 'l-nazmi wajhāni'

or

anna fì 'l-nazmi wujūhan' 10

At times Rāzī seems to be searching for patterns of thought or arrangement in the Qur'anic presentation. Thus, some verses may serve as a muqaddimah to the verses that follow; ${ }^{11}$ it is the Qur'an's practice ('i $d a$ ) to follow up wa'id ("threat") with wa'd ("promise"); ${ }^{12}$ and after adducing arguments in support of a certain claim it has made, the Qur'àn quotes and then replies to objections raised against its claim. ${ }^{13}$ In general, Rāzī tries to see the verses or passages of a sürah as connected from the sürah's beginning to its end. At times, he states his belief in the unity of a sürah quite emphatically. In his commentary on Q 41:44 (wa-law ja'alnāhu Qur'ānan a jamiyyan la-qālū law là fusșilat àyātuhū a-a'jamiyyun wa-'arabiyyun . . .), he rejects the view that this verse was revealed in response to the objection made by some, namely, Why was the Qur'ān not revealed in a language other than Arabic (law là nuzzila 'l-Qur'ānu bi-lughti 'l-Ajami $\left.i^{14}\right)$. To cite such a sabab al-nuzül for this verse is, Rāzì says, to commit a great wrong against the Qur'ān (hayfun 'azimun 'alà 'l-Qur'āni), for it implies that the Qur'ān contains irrelevant verses, and if this indeed were the case, then how could one claim the Qur'ān to be a well-ordered book (kitāban muntazaman), not to speak of claiming inimitability for it (fadlan 'an iddi 'ẩ kawnihi mu 'jizan)? He then remarks that this verse, like the other verses in the sürah, are tied to verse 5 of the sürah. Rāzi concludes by saying:

Ibid., 2:33, at Q 2:5; 9:22, at Q 3:145; 9:83, at Q 166-167.

$10 \quad$ Ibid., 9:9, at Q 3:135; 9:116, at Q 3:181-182; 9:43, at Q 3:154; 9:77, at Q 3:164; 9:129, at Q 3:187.

11 For example, Q 3:137-138, which are a muqaddimah to Q 3:139). Ibid., 9:13, at Q 3:137-138.

12 For example, ibid., 2:122, at Q 2:25.

13 Ibid., 2:131, at Q 2:26.

14 Reading law lā nuzzila instead of law nuzzila or nazala. Cf. law lā unzila hādhā 'l-Qur'ānu. . ., in Ṭabarī, 24:80, and Jalāl al-Dīn al-Suyūṭī, Al-Durr al-Manthūr, 6 vols. (Beirut: Muhammad Amīn Damj, 1972), 5:367. 
(wa-qālù qulūbunā fì akinnatin mimmà tad'ünà ilayhi ... .). ${ }^{15}$

Anyone who considers the matter with fairness, shunning arbitrariness, will realize that, if we interpret this verse the way we have, the whole surrah will become, from beginning to end, a single, well-ordered discourse, moving toward a single goal, and so this interpretation is preferable to the one they have presented.

Rāzìs own words are as follows:

Wa-kullu man anșafa wa-lam yata'assaf' 'alima annā idhā fassarnā hādhihī 'l-āyata 'alā 'l-wajhi 'lladhī dhakarnā șārat hādhihī 'l-sūratu min awwalihā ilā ākhirihā kalāman wāḥidan muntaẓaman masūqan naḥwa gharạ̣in wāḥidin fa-yakūnu hādha 'l-tafsīiru awlā mimmā dhakarūhu. ${ }^{16}$

Time and again, Rāzī exclaims how apt or beautiful such and such an arrangement of Qur'anic verses in a given place is; for example: wa-man anșafa 'alima anna hädhä tartìbun hasanun fì 'l-kalämi. ${ }^{17}$

Rāzīs approach to nażm in the Qur'ān calls for a few observations. First, Rāzì views Qửanic naẓm essentially in terms of linear connection: his goal is to show that the verses of a surrah are marked by continuity. He links up the individual verses or passages of a surah as he goes through the surrah, although sometimes, as we saw in the case of sürah 41, he explains the connectedness of a sürah with reference to a principal idea in the sürah. Second, on occasion, but not as a rule, Rāzī invokes Qur'anic ną̧m as a determinant of interpretation, as we saw in his commentary on Q 41:44. In Q 2:213 (käna 'l-näsu ummatan wähidatan fa-ba'atha 'llähu 'l-nabiyyina mubashshirin wamundhirina ...), he interprets the word al-näs to mean, specifically, those who had believed in Moses, the definite article in al-nās being for 'ahd, or prior knowledge, not for istighräq, or thoroughgoing inclusion. Rāzī caps off his interpretation by saying: "And this view agrees with the verse's nazm and accords with what precedes the verse and what follows it" (wa-hädhà 'l-qawlu muțābiqun li-nażmi

\footnotetext{
15 Rāzì, 27:133, at Q 41:44.

16 Ibid., 27:134, at Q 41:44.

17 Ibid., 9:61, at Q 3:159.
} 
'l-āyati wa-muwāfiqun li-mā qablahā wa-li-mā ba'dahā)..$^{18}$ Also, as in the case of Q 41:44, so in some other cases, Rāzī rejects a verse's alleged sabab al-nuzūl if, in his view, it is in conflict with a nazmbased interpretation of that verse. Third, it would be correct to say that the focus of Rāzịs nazm-based approach to the Qurān is the verses of a sürah, although in some cases he tries to establish nazmrelationships between sürahs as well, by linking up the closing verses of one sürah and the opening verses of the next.

\section{$\operatorname{Biq} \bar{a}^{-} \bar{i}$}

Qur'anic naz̧m constitutes a leitmotif in Biqāî̀'s Qur'anic commentary Naẓm al-Durar fì Tanāsub al-Äyäti wa-'l-Suwar. ${ }^{19}$ Biqa ${ }^{-} \bar{i}$ aims to bring out the relationships informing the sequence of the verses in the Qur'anic sürahs as well as of the sūras in the received arrangement of the Qur'ān (munāsabāt tartīb al-suwar wa'l-ayazt).$^{20} \mathrm{He}$ quotes his shaykh, Abū'l-Faḍl ibn 'Abdallāh, who laid down "the fundamental principle for understanding the munassabät of the Qur'anic verses." The principle, as explained by the shaykh, consists in taking the following into consideration: first, the purpose for which a sürah has been revealed (al-gharadu 'lladhi sïqat lahì 'l-süratu); second, the propaedeutics called for by that purpose (mä yahtäju ilayhi dhälika 'l-gharadu mina 'l-muqaddimäti), and the varying levels of those propaedeutics in so far as they stand in proximity to or at a remove from the purpose in question ( $f \bar{i}$ marătibi tilka 'l-muqaddimäti fì 'l-qurbi wa-'l-bu'di mina 'l-mațlübi); and, third, with discussion of the propaedeutics under way, what that purpose calls for next in terms of the need for the listener to consider the rules and corollaries that follow logically and are necessitated by baläghah (mà yastatbiuhū min istishräfi nafsi 'l-sämi î ilä 'l-ahkämi wa-'l-lawäzimi 'l-täbi'ati lahü 'llatī taqtaḍi 'l-baläghatu). Abū 'l-Faḍl, concludes: "This, then, is the general principle that controls the process of establishing connections between all parts of the Qur'ān (al-amru 'l-kulliyyu 'l-muhayminu 'alä hukmi 'l-rabți bayna jamīi ajzäi 'l-Qur'ani), and when you put it into practice, you will, God Ibid., 6:14-15, at Q 2:213.

19 Abū 'l-Ḥasan Ibrāhīm ibn 'Umar al-Biqā̄ī, Naẓm al-Durar, 8 vols. (Beirut: Dār alKutub al-'Ilmiyyah, 2003).

20 Ibid., 1:3. 
willing, clearly see the nature of nazm in detail—between one verse and another and between one sürah and another."21

In commenting on the opening sürah of the Qur'ān, al-Fätihah, Biqāi $\bar{i}$ says that the gharad of the sürah is to affirm that praise of all kinds is due to God, who ought to be qualified with all the attributes of perfection (ithbätu istihquäqi 'llähi ta'äla li-jamīi 'l-mahämid wasifäti 'l-kamäli), that He alone is the owner and possessor of this world and the next (ikhtișāṣibi bi-milki 'l-dunyā wa-'l-äkhirati), and that He alone is worthy of being worshiped and petitioned for help (wa-bi 'stihquaqqi 'l-ibädati wa-'l-isti'änati), being the only one worthy of being petitioned for the favor of guiding people to the path of those who will succeed and of rescuing them from the path of those who will suffer perdition (bi-'l-su'äli fi 'l-manni bi-ilzämi șiräti 'l-fäizina wa-'l-inqädhi min țarīqi 'l-hälikina mukhtașsan bi-dhälika kullihì). All of this hinges on, says Biqā' $\overline{1}$, on people worshiping, out of fear and awe, God alone (wa-madāru dhälika kullihì murāqabatu 'l-ibädi li-rabbihim li-ifrädibi bi 'l-ibädati), and this is, according to Biqā̄in, what the sürah aims to bring into relief. ${ }^{22}$

Biqāîs's theoretical statement about determining the nazm of a surrah through identification of the surrah's gharad raises hopes that are only marginally fulfilled in his tafsir . As can be seen from his comments on Fätihah, his statement of the surrah's gharad lacks specificity, amounting as it does to a summary or paraphrase of the entire sürah. After discussing the sürah's gharad, Biqā'i explains the sürah's verses by breaking each verse down into shorter pieces - words and phrases - and then tries to point out the connections between these pieces. A certain adhocism informs his approach, however: instead of taking a synoptic view of the surrah's verses and linking them up in light of the sürah's gharad, Biqāi connects any two verse segments as if in isolation from the rest of the surrah's verses.

Similarly, Biqāi îs attempt to discover nazm in the sequence of the sürahs yields mixed results. He says, rightly, that the opening surah, Fätihah, is connected with the following sürah, Baqarah, through the notion of huda, "guidance": in Fätihah, one prays for guidance-

21 Ibid., 1:11.

22 Ibid., 1:12. 
ihdinā 'l-siräta 'l-mustaqìma-(Q 1:6), and Baqarah opens with the statement that the Qur'ān is a guidance for the righteous—hudan li 'l-muttaqina (Q 2:2). But this is a verbal, not a substantive, connection. One of the strangest ways in which Biqāi $\overline{1}$ establishes nazm connections is by reference to the linguistic properties of the Arabic alphabetical characters. His view of the relationship between sürahs 19, Maryam and 20, Tāhāa, is an example. According to him, the last part of surah 19 suggests the possibility that Muhammad may not come to have a large enough following, but surrah 20 says that the exact opposite will happen, as is borne out, says Biqā $\bar{i}$, by the wide span between the points of articulation of the two broken letters opening the sürah - the head of the tongue (ra's al-lisän) in the case of the first letter, $t a$, and the deepest part of the throat (aqșäl-halq) in the case of the second letter, $h a{ }^{23}$

Biqāī claims to have broken new ground in the field of Qur'anic munāsabāt or nazm: he has written a tafsīr, he says, "in an area in which I have not seen anyone having preceded me" ( $f \bar{i}$ fannin $m \bar{a}$ ra'aytu man sabaqanī ilayhi). ${ }^{24}$ This claim is a little surprising since he quotes Zarkashîs treatment of the issue of nazm, which includes a clear reference to Rāzī as one who has dealt with Qur'anic naẓm extensively. ${ }^{25}$

\section{Farāhī and Iṣlāḥi}

Ḥamīd al-Dīn al-Farāhī was an Indian Muslim scholar of the Qur'ān. An author of many books in Arabic, his principal contribution to Qur'anic studies consists in his theory of Qur'anic naẓm. Farāhī enunciated a series of principles concerning Qur'anic nazm and wrote a commentary on a number of Qur'anic sürahs. His student, Amin Aḥsan Iṣlāhịi, who later moved to Pakistan, also made the Qur'ān the focus of his work. He developed Farāhï's exegetical principles and applied them to the entire Qur'ān, producing a nine-volume Qur'anic commentary, Tadabbur-i Qur'ann, ${ }^{26}$ in Urdu.

\footnotetext{
23 Ibid., 5:3, at Q 20:1.

24 Ibid., 1:3.

25 Ibid., 1:5-6.

26 Amīn Aḥsan Iṣlāḥ̄, Tadabbur-i Qur'ān, 9 vols. (Lahore: Fārān Foundation, 2000).
} 
Farāhī is the first Qur'anic exegete to have offered a detailed theoretical argument in support of the view that the Qur'àn is marked by thematic and structural nażm. He quotes Jalāl al-Dīn al-Suyūtị (1445-1505) to the effect that very few exegetes have dealt with this subject because of its subtle, and, therefore, challenging nature. ${ }^{27}$ Farāhī offers his own interpretation of the exegetes' general indifference to nazm in the Qur'ān. He says that the exegetes did recognize the existence of nazm in some parts of the Qur'àn but, failing to discover nazm in all of the Qur'ān, and reluctant, therefore, to declare that the Qur'ān possesses nażm in some parts but not in others, and, thus, wishing to hold a consistent view about the Qur'ann, thought it expedient to deny the existence of nażm in the Qur'ān altogether. ${ }^{28}$ Farāhì also sees significance in the fact that the compilatory order of the Qur'an is different from its revelatory order: Muhammad used to arrange the Qur'anic verses and chapters in an order very different from that in which they were revealed to him, and this new order, as the reports indicate, was governed by considerations of nazm. After all, asks Farāhī, if we were to assume that the Qur'ān is devoid of nazm, then the Qur'anic stricture against poets (Q 26:225), namely, a-lam tara annahum $f_{\bar{i}}$ kulli wädin yahimüna, "Have you not seen that they roam about in every valley," would apply to the Qur'ān, too, for this roaming about-hayamann-is obviously so called by the Qur'ān because it lacks direction, purpose, or plan (hali 'l-hayamānu fì kulli wädin illa 'l-jarayānu fí 'l-qawli min ghayri maqșidin wa-nizämin). ${ }^{29}$

Farāhī then discusses the notion of naẓm within a sürah and nazm between sürahs. Key to finding nażm within a sürah is the concept of 'amüd, or central idea. Every sürah of the Qur'ān revolves around an 'amüd, and all the verses of a sürah are organically linked to it, representing, in light of that 'amüd, a systematic unfolding of the contents of that sürah from its beginning to its end. Farāhīs Tafsir Nizām al-Qur'ān contains an exegesis of fourteen relatively short

\footnotetext{
27 Hamīd al-Dīn al-Farāhī, Tafsìr Niẓām al-Qur'ān (Azam Garh, Uttar Pradesh, India: al-Dāirah al-Hamīdiyya, 2008), 16.

28 Hamīd al-Dīn al-Farāhī, Dalä̉il al-Nizām, in Rasāil al-Imām al-Farāhī, First Series, 3rd printing (Azam Garh, Uttar Pradesh, India: al-Dāirah al-Hamīdiyyah, 2005), 35.

29 Ibid., 33.
} 
sürahs: 1 (Fātihah), 51 (Dhāriyāt), 66 (Tahrīm), 75 (Qiyāmah), 77 (Mursalāt), 80 ('Abasa), 91 (Shams), 95 (Tìn), 103 ('Asr), 105 (Fì), 108 (Kawthar), 109 (Käfirün), 111 (Lahab), and 112 (Ikhlāṣ).We will take a brief look at Farāhîs treatment of sürah 51.

According to Farāhī, the sürah's 'amūd is affirmation of the

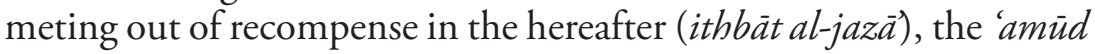
of the preceding surrah, $50(Q \bar{a} f)$, being affirmation of resurrection (ithbät al-ba'th). ${ }^{30}$ This 'amud is developed in the seven sections into which Farāhì divides the sürah's verses, namely: verses 1-14, 15-19, $20-23,24-37,38-46,47-51$, and 52-60. The first section draws attention to the fact that such phenomena of nature as winds and rains are at times beneficial and at times harmful. As such, they point to, and may be called analogues of, reward and punishment in the afterlife, the first section referring to punishment, with the next section speaking of reward, in the hereafter. The third section supports the reward-and-punishment thesis by citing, as evidence, natural phenomena and human life. The sixth section connects the important theme of the hereafter with two other fundamental themes in the Qur'ān, namely, monotheism and prophecy. The concluding section offers solace to the Prophet, telling him that his opponents will suffer the consequences of their disbelief. As can be seen, the sürah's 'amüd, as stated by Farāhī, knits the whole sürah into a unity, and is itself developed quite logically, addressing, in the last section, the actual situation obtaining in Mecca in which the sürah was revealed. ${ }^{31}$

As mentioned above, Iṣlāhī applies, with additions and modifications, Farāhî's methodology to the whole of the Qur'ann, producing a complete Qur'anic tafsir. He identifies the 'amüd of each surrah, usually in quite precise terms. In addition, he establishes, within the received version of the Qur'ān, what he calls surrah-pairs. He maintains that, as a rule, the sürahs exist in pairs, sürahs 2 and 3, 4 and 5, 6 and 7, and 8 and 9, for example, each forming a pair whose member sürahs have complementary 'amüds. Furthermore-and, again, within the received sequence of the Qur'anic surahs-the 114

\footnotetext{
30 Farāhī, Tafsìr Niẓām al-Qur'ān, 119.

31 Mustansir Mir, Coherence in the Qur'an (Indianapolis, IN: American Trust Publications, 1986), 39-41.
} 
sūrahs of the Qur'ān exist as seven groups (as opposed to Farāhīs nine groups), each group comprising one or more Meccan and Medinan surahs, with each type forming a solid bloc-the Meccan preceding the Medinan-and each sürah in a group possessing an 'amüd that deals with one aspect of the group's master 'amüd. ${ }^{32}$ The key notion in Ișlāhī's scheme, as in Farāhì's, is that of the 'amūd of a sürah, and, in another study, I hope to demonstrate, with reference to the longest sürah of the Qur'ān, Baqarah, how Ișlāhī presents, in light of that surrah's 'amūd, a strong case for organic unity in the Qur'anic sürahs.

While the subject of Qur'anic nazm needs to be discussed in much greater details before it will yield more definitive results, it is not difficult to see that, within the compass of this paper and on the basis of prima facie evidence, the Farāhī-Ișlāḥi view of Qur'anic $n a z m$ is more rigorous and systematic than any other author's view of Qur'anic nazm.

\section{Conclusions}

1. In this paper, I have confined my discussion of Qur'anic nazm to works of tafsìr, but treatments of nazm in the Qur'ān are found in extra-exegetical works as well. A number of writers on balāghah, such as Abū Sulaymān Hamd ibn Muḥammad al-Khatṭābī (319-388/931-998), Abū Bakr Muhammad ibn al-Ṭayyib al-Bāqillanī (338-403/950-1013), and Abū Bakr 'Abd al-Qāhir ibn 'Abd al-Raḥmān al-Jurjānī (d. 471/1078), have also dealt with the subject, but their understanding of nazm in the Qur'àn usually does not go beyond the notion of ideal relationship between words and meanings. ${ }^{33}$

2. Historically, there has been a difference of opinion on the issue of the presence of nazm in the Qur'ān. According to the majority view, reported by Zarkashī, ${ }^{34}$ nazm is not part of the "design" of the Qur'ān, since the Qur'ān, revealed in installments over a period of twenty odd years, and its verses

For details, see ibid.

Ibid., 11-16.

34 Zarkashī, 1:37. 
occasioned by a variety of factors and dealing with a variety of injunctions, could not be expected to possess nazm in any significant degree (1:37). According to the minority view, the Qur'ān is possessed of nazm, significant in a limited sense. ${ }^{35}$ Our review of the tafäsìr of selected writers has shown that those who believe that the Qur'ān possesses nazm have understood Qur'anic nazm to have taken one or more of the following forms: nazm as continuity, nazm as context, and nazm as coherence.

3. If we divide tafsìr works into two categories, traditional and modern, defining, roughly, traditional works as those produced from early Islamic times to the end of the nineteenth century and modern works as those that have come into existence since the beginning of the twentieth century, we will clearly see that the idea of Qur'anic nazm has a notable presence in a few of the traditional works, but does not necessarily register a steady linear progress in the overall history of Qur'anic exegesis. We will also notice that the notion of surah as a unity becomes increasingly important in the twentieth century, until it becomes a distinctive feature of modern Qur'anic exegesis. Not only has the idea of Qur'anic nazm made notable gains intwentieth-century Qur'anic exegetical thought, it is likely to become a fundamental premise for study of the Qur'ān in the future. A number of Qur'anic exegetes and scholars in various parts of the Muslim world have approached the Qur'ān with this premise of nazm in mind. A few names are 'Izzat Darwazah, author of Al-Tafsìr al-Hadìth, Sayyid Quṭb, author of Fì Zilāl al-Qur'ān, Ashrāf 'Alī Thānavī, author of the Urdu Bayān al-Qur'àn, Abū 'l-A'lā Mawdūdī, author of Tafhim al-Qur'ān, and Muhammad Husayn alTabātabāī, author of Al-Mizān fì Tafsìr al-Qur'ān. ${ }^{36}$ What we have called above the minority view is likely eventually to become the majority view, making modern tafsir different

Ibid., 1:36.

For details, see Mustansir Mir, "The süra as a unity: a twentieth-century development in Qur'ān exegesis," in G. R. Hawting and Abdul-Kader A. Shereef, eds., Approaches to the Qur'ann (London and New York: Routledge, 1993), 211-224. 
from traditional tafsir in a fundamental respect. Whether this shift in Qur'anic exegetical thought will grow to become, or will contribute along with other changes to the creation of, a sort of paradigm shift in Qur'anic exegesis will depend on how the idea is developed, and with what results. We saw that Rāzì rejects a certain sabab al-nuzūl on the grounds that it undermines Qur'anic nazm, and it would not be wrong to say that there is a certain lack of affinity between Qur'anic $n a z m$ and sabab al-nuzīl. Already in modern tafsìr, there is much less reliance on sabab al-nuz $\bar{u}$ as a determinant of exegesis, and this trend is likely to grow in the future.

4. The interest taken by modern exegetes in Qur'anic nazm can be termed part of a general interest taken by Muslim scholars today in coming to terms with the Qur'ān afresh. This general interest is largely due to the particular sociocultural setting of the Muslim world in modern times. After centuries of stagnation and decadence, on the one hand, and the long, and still continuing, struggle both against the neocolonial domination of Muslim lands and against the self-doubting, obsequious Muslim mindset engendered under colonialism, on the other hand, the Muslims are going through a period of soul-searching under the twin impact of Western thought and culture and Muslim reformist thought. A significant feature of this soul-searching is scrutiny and evaluation of the traditional intellectual and spiritual heritage of Muslims, and, in this project of critical assessment, the Qur'ān, the one constant and irreducible source of knowledge and inspiration for Muslims, is playing an increasingly important role as judge and arbiter of meaning. Conscious that the traditional ways of interpreting the Qur'ān come laden with historical baggage of various kinds, many modern Muslim scholars in modern times attach diminished importance to several traditionally important exegetical sources and have chosen to focus on the Qur'anic text itself, studying it with a view to finding answers and solutions to questions and issues of today. In doing so, they tend to accord primacy to the Qur'anic text itself over the traditional repertoire of sources and devices for understanding that text. Viewed against this 
changed backdrop, a nazm-based approach to the Qur'ān, with its prospects of a more meaningful interpretation of the Qur'ān, would seem to carry great appeal for Muslim exegetes. 